\title{
Early Serum HBV RNA Level in Combination With the HBeAg Response Can Effectively Predict the HBeAg Response in Patients on Nucleos(t)ide Analogue Therapy (ClinicalTrials.gov (NCT03909191)
}

\section{YAYUN LIU}

Department of Infectious Diseases, Changhai Hospital, Second Military Medical University, Shanghai WEI LIAO

Department of Infectious Diseases, Changhai Hospital, Second Military Medical University, Shanghai

\section{AIJING XU}

Department of Infectious Diseases, Changhai Hospital, Second Military Medical University, Shanghai WEI YIN

Department of Infectious Diseases, Changhai Hospital, Second Military Medical University, Shanghai JIAO YU

Department of Infectious Diseases, Changhai Hospital, Second Military Medical University, Shanghai WENHAN FAN

Department of Infectious Diseases, Changhai Hospital, Second Military Medical University, Shanghai JIANYA XUE

Department of Infectious Diseases, Changhai Hospital, Second Military Medical University, Shanghai

\section{XUESONG LIANG ( $\nabla$ liangxuesong2000@163.com)}

Department of Infectious Diseases, Changhai Hospital, Second Military Medical University, Shanghai

\section{Research Article}

Keywords: pre-genomic RNA (pgRNA), prediction, antiviral therapy, HBeAg seroconversion, hepatitis B virus (HBV)

Posted Date: June 16th, 2021

DOI: https://doi.org/10.21203/rs.3.rs-602096/v1

License: (c) This work is licensed under a Creative Commons Attribution 4.0 International License. Read Full License 


\section{Abstract}

Background: Serum HBV RNA level has the potential to monitor antiviral therapy in patients with chronic hepatitis B. This study aimed to explore serum HBV RNA dynamic change pattern and its predict value on the efficacy of 96 weeks nucleos(t)ide analogue (NA) treatment in HBeAg-positive and HBeAg-negative patients with chronic hepatitis B (CHB).

Methods: A real-life cohort study of 78 patients with CHB on NA treatment was conducted. Dynamic change patterns of serum HBV RNA and correlation with other HBV markers in the early treatment period of 96 weeks of NA treatment in patients with $\mathrm{CHB}$ were determined and compared. The performance of serum HBV RNA on treatment efficacy was analyzed by receiver operating characteristic (ROC) analyses.

Results: HBeAg-positive and HBeAg-negative patients with $\mathrm{CHB}$ had similar viral change patterns during NA treatment. Serum HBV RNA level was consistently correlated with HBeAg and HBsAg titers in HBeAg-positive patients during NA treatment, but serum HBV RNA was only moderately correlated with serum HBV DNA level in HbeAg-negative patients before treatment. Serum HBV RNA decreased more rapidly in patients with the HBeAg seroconversion (SC) response than in patients without the HBeAg SC response; it had good early discriminatory ability for the HBeAg response with area under the ROC curve (AUROC) of 0.70 and 0.730 at 12 and 24 weeks of treatment, respectively. The cutoff value of serum HBV RNA of $4.31 \mathrm{log} \mathrm{cps} / \mathrm{mL}$ in combination with the HBeAg decrease degree of 1.55 at 24 weeks of treatment had a good twoway predictive capability for the HBeAg response (PPV\%: $83.33 \%$ and NPV\%: $81.25 \%$ ), and the specificity was $96.30 \%$.

Conclusion: Serum HBV RNA level had early discriminatory ability for the HBeAg response. Early HBeAg response can improve the discriminatory ability of serum HBV RNA.

\section{Introduction}

Long-term nucleos(t)ide analogue (NA) treatment can improve liver inflammation, ameliorate the development of liver fibrosis, and reduce the risk of hepatocellular carcinoma (HCC) through efficient suppression of hepatitis B virus (HBV) replication. However, given the limited effect on covalently closed circular DNA (cccDNA), NA therapy rarely leads to a functional cure (defined as hepatitis B surface antigen [HBsAg] loss with undetectable HBV DNA)[1-3]. HBeAg loss and seroconversion (SC) are associated with immune restoration and can be the impetus for HBsAg loss and SC[1, 2, 4, 5]. Therefore, to improve treatment responses, pretreatment and on-treatment viral factors must be assessed.

Several HBV biomarkers, including HBV DNA, HBsAg titer, and hepatitis B core-related antigen (HBcrAg), have been used to monitor HBV chronic infection and antiviral therapy[6-10]. Unfortunately, these indicators are currently unable to effectively predict or guide NA therapy alone. Serum HBV RNA, a new surrogate for intrahepatic cccDNA transcription, has the potential to monitor chronic HBV infection, and a growing body of research suggested that serum HBV RNA may be a useful marker for monitoring chronic HBV infection including natural history, treatment, and prognosis[11-19]. However, previous research yielded inconsistent results, such as the correlation between serum HBV RNA and other viral markers in HBeAg-positive and HBeAg-negative patients with or without antiviral treatment[19-20], early serum HBV RNA kinetics in patients on NA therapy[21], and the potential use of serum HBV RNA and the cutoff value of serum HBV RNA level for prediction[22].

In this work, we aimed to determine the early kinetics of serum HBV RNA in HBeAg-positive and HBeAg-negative patients and evaluate the performance of early-stage serum HBV RNA for monitoring NA therapy patients with chronic hepatitis B (CHB).

\section{Methods And Materials}

\section{Study design}

Page $2 / 14$ 
A real-life cohort study was conducted in Shanghai Changhai Hospital between February 12, 2016 and February 21, 2018. Dynamic change patterns of serum HBV RNA in different patients with CHB undergoing long-term antiviral treatment were determined and compared. Furthermore, the role of serum HBV RNA alone or in combination with other HBV biomarkers on the treatment efficacy of HBeAg-positive patients with $\mathrm{CHB}$ was explored. The study was approved by the ethics research committee (CHEC2019-056) of Shanghai Changhai Hospital and registered on ClinicalTrials.gov (NCT03909191). Written informed consent was obtained from each patient.

\section{Patients}

Patients enrolled met the following criteria: positive for HBsAg more than 6 months before enrollment; alanineamino transferase (ALT) level higher than the upper limit of detection (14 days interval); no decompensated cirrhosis; no hepatitis C, hepatitis D, or human immunodeficiency virus co-infection; no HCC and other tumors or history of severe hepatitis; and no other systemic diseases, such as a history of cardiopulmonary diseases, thyroid disorders, immune system disorders, epilepsy, or mental illness (such as severe depression). The patients enrolled in this study were treated with first-line NAs or Peg interferon (IFN), followed by a switch to NAs for 96 weeks.

\section{Antiviral response definition}

HBeAg SC was defined as the loss of HBeAg and the appearance of anti-HBeAg on two occasions, at least one month apart in HBeAg-positive patients during 96 weeks of NA treatment.

For subsequent analyses, HBeAg-positive patients who achieved HBeAg SC and those who did not achieve $\mathrm{HBeAg}$ seroconversion (NSC) were divided into the SC and NSC groups, respectively.

\section{Serological and virological detection}

\section{Serum HBV RNA quantification}

Serum HBV RNA was detected by RNA simultaneous amplification (SAT) using the commercially available HBV-SAT kit (Rendu Biotechnology, Shanghai, China) as previously described[11, 12]. Primers and probes were designed to amplify an HBV pre-genomic RNA (pgRNA) conserved region[23]. RNA extraction, amplification, and detection were processed on an automated AutoSAT system (Rendu Biotechnology, Shanghai, China). The HBV RNA assay was calibrated using an armored HBV RNA standard traceable to the HBVRNA standard in vitro transcripts. The minimum detection limit (MDL) was 100 copies $/ \mathrm{mL}$.

The serum HBV RNA test results were classified as follows[12]: (1) "target not detected," (2) "<100 copies/mL," and (3) "a numeric titer of $>100$ copies/mL." Negative HBV RNA was strictly defined as HBV RNA "target not detected." Positive HBV RNA was defined as HBV RNA $<100$ copies/mL or a numeric titer of $>100$ copies $/ \mathrm{mL}$.

\section{Serum HBV DNA quantification}

Serum HBV DNA was quantified by the commercially available hepatitis B viral DNA Determination Kit (Sansure Biotech, China), with a detection range of $1 \times 10^{2} \mathrm{IU} / \mathrm{mL}$ to $5 \times 10^{8} \mathrm{IU} / \mathrm{mL}$. The value below the detection limit was replaced with the low detection limits.

\section{HBV serological test}

Serum HBsAg, HBeAg, anti-HBs, anti-HBe, and anti-HBc were measured by chemiluminescence microparticle immunoassays using the Architect i2000SR platform and Abbott Architect reagents (Abbott Laboratories, North Chicago, IL, USA) in our clinical laboratory. 


\section{Statistical analysis}

The data are presented as the mean, median (interquartile range) or proportion based on data type and distribution. The two groups (SC vs. NSC and HBeAg-positive vs. HbeAg-negative $\mathrm{CHB}$ ) were compared using the Mann-Whitney U test for continuous data and chi-squared test for categorical data. Spearman correlation coefficients $®$ were used to compare the correlation between two variables. Logistic regressions were used to assess the odds ratio and $95 \%$ confidence interval $(95 \% \mathrm{Cl})$ of HBV markers. Receiver operating characteristic (ROC) curves were used to compare the relative sensitivity and specificity of HBV RNA, HBsAg, HBeAg, and HBV DNA as predictors of antiviral efficacy. The cutoff value was chosen based on the ROC curve when the sensitivity and specificity were both relatively high. A P-value (two-tailed) of 0.05 was considered statistically significant. All statistical analyses were carried out using SPSS software (version 21.0.0; Chicago, IL, USA) and GraphPad Prism9 software (GraphPad, NJ, USA)

\section{Results}

\section{Patient characteristics and treatment outcome}

A total of 110 patients with CHB were recruited for this study from February 2016 to December 2018 in Shanghai Changhai Hospital. Finally, 79 patients with CHB (54 HBeAg-positive) were enrolled in this study. All of them were treated for more than 96 weeks with first-line NAs (ETV or TDF).

At baseline, $\mathrm{HBeAg}$-positive patients with $\mathrm{CHB}$ had significantly higher viral replication level compared with $\mathrm{HBeAg}$-negative patients with CHB. However, during the 96 weeks of NA treatment, HBeAg-positive and HBeAg-negative patients achieved similar serum HBV DNA below the MDL (<MDL), HBsAg loss rate, and ALT normalization rate (Table 1). Of these 79 patients with $\mathrm{CHB}$, only one patient achieved HBsAg loss, whereas four patients (two HBeAg-positive and two HBeAgnegative patients with $\mathrm{CHB}$ ) achieved $\mathrm{HBsAg}<100 \mathrm{IU} / \mathrm{mL}$ during the 96 weeks of antiviral treatment. Fourteen (25.93\%) HBeAg-positive patients with CHB achieved SC response. HBeAg-positive patients with SC had significantly higher ALT normalization rate and serum HBV DNA $<$ MDL rate than NSC patients (Table 1). 
Table 1

Clinical Characteristics of patients with $\mathrm{CHB}$

\begin{tabular}{|c|c|c|c|c|c|c|c|}
\hline \multirow[t]{3}{*}{ Characteristics } & \multirow{3}{*}{$\begin{array}{l}\text { Total } \\
(n=79)\end{array}$} & \multirow{3}{*}{$\begin{array}{l}\text { HBeAg pos. } \\
(n=54)\end{array}$} & \multirow{3}{*}{$\begin{array}{l}\text { HBeAg Neg. } \\
(n=25)\end{array}$} & \multirow{3}{*}{$\begin{array}{l}P \\
\text { value }\end{array}$} & \multicolumn{2}{|l|}{ HBeAg Pos. } & \multirow{3}{*}{$\begin{array}{l}P \\
\text { value }\end{array}$} \\
\hline & & & & & SC & NSC & \\
\hline & & & & & $(n=14)$ & $(n=40)$ & \\
\hline $\operatorname{Sex}(M: F)$ & $55: 24$ & $40: 14$ & $15: 10$ & 0,206 & $10: 4$ & $30: 10$ & 1.000 \\
\hline Age(year) & $\begin{array}{l}36.0(30.0- \\
45.0)\end{array}$ & $\begin{array}{l}32.0(29.0- \\
40.0)\end{array}$ & $\begin{array}{l}45.0(37.5- \\
55.5)\end{array}$ & $\varangle 0.001$ & $\begin{array}{l}31.5(27.00- \\
40.00)\end{array}$ & $\begin{array}{l}32.00(30.00- \\
41.5)\end{array}$ & 0.553 \\
\hline \multicolumn{8}{|c|}{ Baseline characteristics } \\
\hline $\begin{array}{l}\text { HBsAg }(\log 10, \\
\mathrm{IU} / \mathrm{ml})\end{array}$ & $\begin{array}{l}3.47(3.08- \\
4.14)\end{array}$ & $\begin{array}{l}3.69(3.22- \\
4.39)\end{array}$ & $\begin{array}{l}3.11(2.75- \\
3.55)\end{array}$ & 0.004 & $\begin{array}{l}3.80(3.20- \\
4.19)\end{array}$ & $\begin{array}{l}3.63(3.20- \\
4.46)\end{array}$ & 0.845 \\
\hline $\begin{array}{l}\mathrm{HBeAg}(\log \\
\text { 10)S/CO }\end{array}$ & $\begin{array}{l}2.81(1.69- \\
3.11)\end{array}$ & $\begin{array}{l}2.81(1.69- \\
3.11)\end{array}$ & / & / & $\begin{array}{l}2.75(1.80- \\
2.96)\end{array}$ & $\begin{array}{l}2.81(1.57- \\
3.16)\end{array}$ & 0.612 \\
\hline $\begin{array}{l}\text { HBV } \\
\text { DNA(log10)IU/ml }\end{array}$ & $\begin{array}{l}6.11(4.41- \\
7.70)\end{array}$ & $\begin{array}{l}7.01(5.51- \\
7.90)\end{array}$ & $\begin{array}{l}4.34(3.51- \\
5.25)\end{array}$ & $\varangle 0.001$ & $\begin{array}{l}7.05(5.32- \\
7.96)\end{array}$ & $\begin{array}{l}7.01(5.64- \\
7.93)\end{array}$ & 0.942 \\
\hline $\begin{array}{l}\text { HBV RNA(log } \\
\text { 10)copies/ml }\end{array}$ & $\begin{array}{l}6.64(5.58- \\
8.08)\end{array}$ & $\begin{array}{l}7.54(5.96- \\
8.30)\end{array}$ & $\begin{array}{l}5.78(5.23- \\
6.42)\end{array}$ & 0.001 & $\begin{array}{l}7.20(5.59- \\
7.97)\end{array}$ & $\begin{array}{l}7.70(6.09- \\
8.68)\end{array}$ & 0.302 \\
\hline $\operatorname{ALT}(\mathrm{U} / \mathrm{L})$ & $\begin{array}{l}105.5(51.5- \\
227.75)\end{array}$ & $\begin{array}{l}105.50(53.75- \\
230.25)\end{array}$ & $\begin{array}{l}101.0(33.25- \\
225.0)\end{array}$ & 0.561 & $\begin{array}{l}255.00(205.5- \\
444.75)\end{array}$ & $\begin{array}{l}73.5(44.5- \\
153.25)\end{array}$ & 0.000 \\
\hline $\operatorname{AST}(\mathrm{U} / \mathrm{L})$ & $\begin{array}{l}66.5(36.0- \\
112.0)\end{array}$ & $\begin{array}{l}68.00(38.75- \\
112.00)\end{array}$ & $\begin{array}{l}63.0(27.0- \\
121.0)\end{array}$ & $0 \rrbracket 663$ & $\begin{array}{l}119.5(73.75- \\
195.0)\end{array}$ & $\begin{array}{l}44.5(31.75- \\
87.00)\end{array}$ & 0.000 \\
\hline \multicolumn{8}{|l|}{ Treatment outcome } \\
\hline $\begin{array}{l}\text { HBV DNA below } \\
\text { MDL }\end{array}$ & $63(78.48)$ & $41(75.93)$ & $22(88.00)$ & 0.214 & $14 / 14(100)$ & $27 / 40(67.5)$ & 0.037 \\
\hline $\begin{array}{l}\text { HBsAg loss } \\
\text { rate,n(\%) }\end{array}$ & $1(1.27)$ & $1(1.85)$ & $0(0)$ & 1.00 & $1 / 14(7.14)$ & $0 / 40(0)$ & 0.259 \\
\hline $\begin{array}{l}\mathrm{HBsAg}< \\
100 \mathrm{IU} / \mathrm{mL} \\
\text { rate,n(\%) }\end{array}$ & $4(5.06)$ & $2(3.70)$ & $2(8.0)$ & 0.796 & 2/14(14.29) & $0 / 40(0)$ & 0.064 \\
\hline $\begin{array}{l}\text { ALT } \\
\text { normalization } \\
\text { rate,n(\%) }\end{array}$ & $60(75.95)$ & $39(72.22)$ & $21(84.00)$ & 0.255 & 14/14(100) & $25 / 40(62.5)$ & 0.000 \\
\hline $\begin{array}{l}\text { Continuity data we } \\
\text { Neg. negative. MD } \\
\text { hepatitis B e antig }\end{array}$ & $\begin{array}{l}\text { shown as m } \\
\text { ninimum de } \\
\text { HBsAg, hep }\end{array}$ & $\begin{array}{l}\text { ian (interquar } \\
\text { ction limit; AL7 } \\
\text { tis B surface a }\end{array}$ & $\begin{array}{l}\text { ange). SC: sf } \\
\text { anine aminot } \\
\text { yen; HBV, hep }\end{array}$ & $\begin{array}{l}\text { onvers } \\
\text { ferase } \\
\text { s B viru }\end{array}$ & $\begin{array}{l}\text { NSC: no seroc } \\
T \text {, aspartate al }\end{array}$ & $\begin{array}{l}\text { nversion; pos. } \\
\text { notransferase }\end{array}$ & $\begin{array}{l}\text { sitive; } \\
\text { IBeAg, }\end{array}$ \\
\hline
\end{tabular}

\section{Correlation between serum HBV RNA and other HBV biomarkers in patients with CHB on NA treatment by baseline HBeAg} status

In HBeAg-positive patients with CHB, before NA treatment, strong correlation was found between serum HBV RNA and HBV DNA (Spearman's $r=0.73$; Fig. 1A), and this strong correlation gradually decreased with treatment (Spearman's $r=0.53$ and 0.41; Figs. 1B and 1C). Furthermore, sustained moderate correlation was noted between serum HBV RNA and HBeAg and HBsAg titer during treatment (Spearman's $r=0.59-0.40$; Figs. 1A-1C). However, in HBeAg-negative patients with $\mathrm{CHB}$ on NA treatment, a significant correlation only existed between serum HBV RNA and HBV DNA level before treatment (Spearman's $r=0.53$; Fig. 1D) and the relationship decreased and disappeared gradually with treatment (Spearman's $r=$ 0.42 and 0.25 ; Figs. 1E and 1F). 
During NA treatment, $\mathrm{HBeAg-positive} \mathrm{and} \mathrm{HBeAg-negative} \mathrm{patients} \mathrm{with} \mathrm{CHB}$ had similar dynamic change patterns of serum HBV biomarkers, including serum HBV RNA, HBV DNA, and HBsAg titers (Figs. 2A-2C). Serum HBV DNA level decreased more rapidly than serum HBV RNA level in total CHB patients and HBeAg-positive patients during the early stage of NA treatment (Figs. 2D and 2E). However, serum HBVRNA and DNA level had similar decrease degrees in HBeAgnegative patients (Fig. 2F).

\section{Dynamic change patterns of serum HBV RNA in HBeAg-positive patients with CHB on NA treatment by serum HBeAg conversion response}

Before initiation of NA treatment, there were no significance difference in the serum HBV RNA and HBV DNA levels between HBeAg-positive patients with or without the HBeAg SC response during the 96 weeks of treatment (Figs. 3A and 3B). However, from week 12 of treatment, absolute values of serum HBV RNA, HBsAg, and HBeAg in patients with the SC response were significantly lower than those in patients without the SC response (Figs. 3B-3D). Consistent with this result, serum HBsAg and HBeAg titers in patients with the HBeAg SC response decreased rapidly from baseline during the first 12 weeks of treatment than that in patients without the HBeAg SC response (Figs. $2 \mathrm{G}$ and $2 \mathrm{H}$ ). However, no significant difference was found between serum HBV RNA and DNA decrease degree in patients with different HBeAg SC responses (Figs. 3E and 3F).

\section{Value of serum HBV RNA in monitoring the HBeAg SC response of NA therapy}

Considering the strong correlation between serum HBV RNA and HBeAg level in HBeAg positive CHB patients before initiation and during NA treatment (Figs. 1A-C), and the significant difference in serum HBV RNA, HBsAg, and HBeAg titers in patients who achieved different HBeAg SC responses on NA treatment (Figs. 3), we illustrated the potential utility of serum HBV RNA in monitoring the HBeAg response of NA therapy. The ROC curves and area under curve (AUROC) scores of absolute and change from baseline levels for all viral indicators are shown in Figs. 4A-4E. Based on the AUROC scores of the absolute values of serum HBV RNA, HBeAg, and HBsAg, the SC responders could be well identified as early as 12 weeks of treatment, with the AUROC scores of $0.703,0.780$, and 0.761 , respectively (Fig. 4B). At 24 weeks of treatment, only the absolute values of HBeAg and HBsAg demonstrated good discriminatory ability, with AUROC scores of 0.789 and 0.717 , respectively (Fig. 4C). The absolute value of serum HBV DNA consistently showed poor discriminatory ability, with AUROC score $\leq 0.631$ (Figs. 4A-4C).

Serum HBV RNA level decrease degree from baseline at 12 and 24 weeks of NA treatment showed poor discriminatory ability, with low AUROC scores (Figs. 4D and 4E), but those for serum HBsAg and HBeAg titers showed similar discriminatory ability to their absolute value at the same time point, especially the HBeAg titer (Figs. 4D and 4E).

\section{Cutoff value of HBV biomarkers to predict the HBeAg SC response of NA therapy}

Considering the higher discriminatory ability of HBV biomarkers' absolute value and decrease degree from baseline at the early stage of treatment for the HBeAg response of NA treatment and the characteristics of HBV biomarkers' dynamics during NA treatment, the cutoff values of these HBV biomarkers at 12 and 24 weeks of treatment were identified. Moreover, their performance was compared.

At the early stage of treatment, serum HBV RNA level consistently showed good predictive ability for the HBeAg response during 96 weeks of NA treatment. The absolute values of serum HBV RNA of 4.94 (log cps/mL) at 12 weeks and 4.31 (log $\mathrm{cps} / \mathrm{mL}$ ) at 24 weeks of treatment both had good negative predictive value (NPV) for the HBeAg SC response ( $90.48 \%$ vs. $94.74 \%$ ), and both possessed high sensitivity (83.33\% vs. $90.0 \%$, respectively). Classical viral indicators, HBsAg cutoff value of $3.46 \log _{10} \mathrm{IU} / \mathrm{mL}$ at 12 weeks of treatment, and HBeAg value of $2.87 \log _{10} \mathrm{~S} / \mathrm{CO}$ at 12 weeks of treatment also 
had good NPV\% (> 80\%) for the HBeAg SC response (Table 2). The 24-week HBeAg cutoff value of $0.306 \log _{10} \mathrm{~S} / \mathrm{CO}$ showed a two-way predictive capability for the HBeAg response (PPV\% and NPV\% both > 80\%; Table 2). In addition to the absolute cutoff value of $\mathrm{HBeAg}$, the titer decreases from baseline with a cutoff value of $1.55 \mathrm{log} \mathrm{IU} / \mathrm{mL}$ at 24 weeks of treatment had a good NPV\% (86.47\%) and high specificity (86.49\%) (Table S1).

Table 2

Absolute cutoff value of HBV biomarkers at 12 and 24 weeks of treatment for predict HBeAg seroconversion.

\begin{tabular}{|c|c|c|c|c|c|}
\hline characteristics & Cutoff values & Sensitivity, \% & Specificity, \% & PPV, \% & NPV, \% \\
\hline \multicolumn{6}{|l|}{12 weeks of treatment } \\
\hline HBV RNA, $\log _{10} \mathrm{cps} / \mathrm{mL}$ & 4.94 & 83.3 & 55.88 & 40 & 90.48 \\
\hline HBeAg, log S/CO & 2.87 & 78.57 & 32.5 & 28.95 & 81.25 \\
\hline $\mathrm{HBsAg}, \log _{10}(\mathrm{IU} / \mathrm{ml})$ & 3.46 & 84.62 & 59.46 & 42.31 & 91.67 \\
\hline \multicolumn{6}{|l|}{24 weeks of treatment } \\
\hline HBV RNA, $\log _{10} \mathrm{cps} / \mathrm{mL}$ & 4.31 & 90.0 & 62.07 & 45 & 94.74 \\
\hline $\mathrm{HBeAg}, \log _{10} \mathrm{~S} / \mathrm{CO}$ & 0.306 & 57.15 & 95 & 80 & 86.36 \\
\hline $\mathrm{HBsAg}, \log _{10}(\mathrm{IU} / \mathrm{ml})$ & 2.89 & 57.14 & 85 & 57.14 & 57.14 \\
\hline
\end{tabular}

\section{Serum HBV RNA combined with a sharp decline in HBeAg can better predict the HBeAg response}

To find better predictors for the HBeAg response, we explored the predictive value of serum HBV RNA in combination with other classical HBV biomarkers and found that serum HBV RNA combined with HBeAg had good predictive value and high AUROC scores (0.854, 95\% Cl: $0.754-0.954$; Table S2). The absolute cutoff value of serum HBV RNA of 4.31 combined with $\mathrm{HBeAg}$ decrease degree of 1.55 at 24 weeks of treatment had a good two-way predictive capability for the HBeAg response (PPV\%: 83.33\% and NPV\%: 81.25\%), and the specificity was 96.30\% (Table S2).

\section{Discussion}

Here, we longitudinally studied the dynamic pattern of serum HBV RNA profiles in HBeAg-positive or HBeAg-negative patients with $\mathrm{CHB}$ subjected to NA treatment. This work aimed to reveal whether serum HBV RNA has similar value in monitoring the antiviral response in HBeAg-positive and -negative patients. We found that the dynamic change pattern of serum HBV RNA in HBeAg-positive patients on long-term NA treatment mirrored that of serum HBV DNA, HBsAg, and HBeAg. Serum HBV RNA sustained moderate to strong correlation with these viral markers. However, the correlation between serum HBV RNA and other HBV biomarkers was not sustained in HBeAg-negative patients with CHB during NA treatment. These results indirectly illustrated that serum HBV RNA quantification may play a potential monitoring value on the NA treatment response in $\mathrm{HBeAg}$-positive patients with $\mathrm{CHB}$, other than in HBeAg-negative patients.

As a surrogate biomarker for intrahepatic cccDNA quantity and transcript activity, serum HBV RNA level has been confirmed to be a valuable marker for $\mathrm{CHB}$ management, including natural course management and antiviral management[10-16, 18-20, 24-27]. Our previous study and other researches revealed that serum HBV RNA alone or combined with other viral indicators such HBsAg titer or HBcrAg level can guild antiviral cessation in patients with $\mathrm{CHB}[12$, $15,16,28]$. In this study, we further studied the monitoring value of serum HBV RNA on the NA treatment response. We 
found no difference in serum HBV RNA level at baseline between patients with the SC response or not, but serum HBV RNA level in patients with the SC response was obviously lower than that in patients without the SC response at the early stage of NA treatment. Moreover, the AUROC values of serum HBV RNA at 12 and 24 weeks of treatment exceeded 0.70 , indicating that serum HBV RNA level had early predictability of the HBeAg SC response in patients on NA treatment. We then analyzed the absolute cutoff value of serum HBV RNA at 12 and 24 weeks of treatment separately and found that the cutoff of HBV RNA at 4.94 or $4.31 \log 10$ copies/mL at 12 and 24 weeks of treatment, respectively, had the highest NPV for the $\mathrm{SC}$ response in NA treatment. All these results confirmed that serum HBV RNA alone showed good discriminatory ability for the antiviral response on NA treatment. Compared with HBeAg level and HBsAg titer of the same time point, serum HBVRNA alone had no obvious advantage in predicting the antiviral response. Further analysis of the NA treatment response of HBV biomarkers demonstrated no obvious advantage of serum HBV RNA in predicting the SC response during 96 weeks of NA treatment. However, serum HBV RNA value combined with HBeAg decrease degree at 24 weeks of NA treatment showed a good predictive value for the SC response, with high specificity and AUROC value. These results were similar to the findings reported by Wang[18] and Luo[29], who both found that the combination of serum HBV RNA and $\mathrm{HBeAg}$ response shows better predicting value for NA treatment response than serum HBV RNA alone.

Although our results here and the findings of previous studies revealed that serum HBV RNA alone or in combination with HBeAg treatment response can monitor NA treatment early, the cutoff values of serum HBV RNA in the literature varied widely[16, 29]. This difference may be related to the methodological heterogeneity of serum HBV RNA detection. Given the complexity of serum HBV RNAs, serum HBV RNA levels detected by different primers targeting varying regions of the HBV genome were not only inconsistent[30] but also different in treatment outcomes[31]. Therefore, before serum RNA is applied to clinical practice in the future, further understanding of the biological significance of serum HBV pgRNA and standardization of testing methods is critical.

As a real-life cohort study, our results were more representative of the clinical reality than team-registered studies. However, our study had some shortcomings, such as a relatively small sample size, and the significance of serum HBV RNA prediction needs to be further verified in larger sample sizes. Moreover, in our study, HBeAg was measured using a chemiluminescence microparticle immunoassay, which is the most common assay method in China but not a total quantitative test. Despite these limitations, the HBeAg level still has meaningful reference value in clinical practice.

\section{Conclusion}

In conclusion, serum HBV RNA level change pattern in HBeAg positive and negative CHB patients on NA therapy was different, serum HBV RNA level had good correlation with other viral markers, such as HBV DNA level, HBeAg level and HBsAg titer, in HBeAg positive CHB patients during NA treatment. Serum HBV RNA level had early discriminatory ability for the HBeAg response, and early HBeAg decrease degree from baseline can improve the discriminatory ability of serum HBV RNA.

\section{Abbreviations}

NA:nucleos(t)ide analogue; HCC:hepatocellular carcinoma; cccDNA: hepatocellular carcinoma;HBsAg: hepatitis B surface antigen; SC: seroconversion; HBcrAg:hepatitis B core-related antigen;CHB: chronic hepatitis B; ALT: Alanineamino transferase; NSC: no seroconversion;SAT:simultaneous amplification;pg-RNA: pre-genomic RNA;MDL: minimum detection

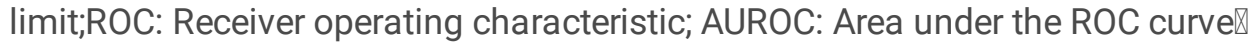

\section{Declarations}

\section{Ethics approval and consent to participante}


This study was approved by the Ethics Committee of Changhai Hospital. (CHEC2019-056). Written informed consent was obtained from all the study participants.

\section{Consent for publication}

Not applicable

\section{Availability of data and material}

All data and analysis results are included in this article. The data sets used and/or analyzed during the current study are available from the corresponding author on reasonable request.

\section{Competing interests}

The authors declare that they have no competing interests.

\section{Funding}

This study was supported by Beijing Medical Health Foundation-Medicine Science Study (No. YWJKJJHKYJJ-G17007), Grants from Shanghai Natural Science Fund (No.16ZR1400400, 20ZR1456900), and Wu Jieping Medical Foundation (LSWJPMF-102-17001). The fund units are not involved in the design, analysis, and conduct of this study.

\section{Authors' contributions}

LYY recruited the patients and collected specimens, edited the clinical data and performed the data analysis;

LW enrolled and followed the patients, edited the clinical data of enrolled patients;

XAJ, YW, YJ, FWH, XJY treated and followed the patients;

LXS conceived and designed the study; checked the data analysis and drafted the manuscript;

All authors have read and approved the final manuscript.

\section{Acknowledgment}

The authors thank Dr Qian He (Department of Health Statistics, Second Military Medical University, Shanghai) for giving helpful comments in data analysis and confirmation of statistical methods.

\section{References}

1. Terrault NA, Bzowej NH, Chang KM, Hwang JP, Jonas MM, Murad MH; American Association for the Study of Liver Diseases. AASLD guidelines for treatment of chronic hepatitis B. Hepatology. 2016,63(1):261-83.

2. European Association For The Study Of The Liver. EASL clinical practice guidelines: Management of chronic hepatitis B virus infection. J Hepatol. 2012,57(1):167-85.

3. Sarin SK, Kumar M, Lau GK, Abbas Z, Chan HL, Chen CJ, et al. Asian-Pacific clinical practice guidelines on the management of hepatitis B: a 2015 update. Hepatol Int. 2016,10(1):1-98.

4. Fattovich G, Olivari N, Pasino M, D'Onofrio M, Martone E, Donato F. Long-term outcome of chronic hepatitis B in Caucasian patients: mortality after 25 years. Gut. 2008,57(1):84-90.

5. Evans A, Riva A, Cooksley H, Phillips S, Puranik S, Nathwani A,et al. Programmed death 1 expression during antiviral treatment of chronic hepatitis B: Impact of hepatitis B e-antigen seroconversion. Hepatology. 2008,48(3):759-69. 
6. Lau G,Marcellin P,Brunetto M,Brunetto M,Piratvisuth T,Popescu M.On treatment monitoring of HBsAg levels to predict response to peginterferon alfa-2a in patients with HBeAg-positive chronic hepatitis B. J Hepatol.2009,50(09):S333.

7. Moucari R, Mackiewicz V, Lada O, Ripault MP, Castelnau C, Martinot-Peignoux M, et al. Early serum HBsAg drop: a strong predictor of sustained virological response to pegylated interferon alfa-2a in HBeAg-negative patients. Hepatology. 2009,49(4):1151-7.

8. Janssen HL, Kerhof-Los CJ, Heijtink RA, Schalm SW. Measurement of HBsAg to monitor hepatitis B viral replication in patients on alpha-interferon therapy. Antiviral Res. 1994,23(3-4):251-7.

9. Chan HL, Wong VW, Wong GL, Tse CH, Chan HY, Sung JJ. A longitudinal study on the natural history of serum hepatitis B surface antigen changes in chronic hepatitis B. Hepatology. 2010,52(4):1232-41.

10. Fan R, Peng J, Xie Q, Tan D, Xu M, Niu J, et al. Combining Hepatitis B Virus RNA and Hepatitis B Core-Related Antigen: Guidance for Safely Stopping Nucleos(t)ide Analogues in Hepatitis B e Antigen-Positive Patients With Chronic Hepatitis B. J Infect Dis. 2020,23;222(4):611-18.

11. Liu Y, Jiang M, Xue J, Yan H, Liang X. Serum HBV RNA quantification: useful for monitoring natural history of chronic hepatitis B infection. BMC Gastroenterol. 2019,16;19(1):53.

12. Liu Y, Xue J, Liao W, Yan H, Liang X. Serum HBV RNA Dynamic and Drug Withdrawal Predictor Value in Patients With Chronic HBV Infection on Long-term Nucleos(t)ide Analogue (NA) Therapy. J Clin Gastroenterol. 2020,54(8):e73-e82.

13. Wang J, Shen T, Huang X, Kumar GR, Chen X, Zeng Z, et al. Serum hepatitis B virus RNA is encapsidated pregenome RNA that may be associated with persistence of viral infection and rebound. J Hepatol. 2016,65(4):700-710.

14. Wang J, Yu Y, Li G, Shen C, Meng Z, Zheng J,et al. Relationship between serum HBV-RNA levels and intrahepatic viral as well as histologic activity markers in entecavir-treated patients. J Hepatol. $2017,21:$ S0168-8278(17)32261-4.

15. van Bömmel F, van Bömmel A, Krauel A, Wat C, Pavlovic V, Yang L, et al. Serum HBV RNA as a Predictor of Peginterferon Alfa-2a Response in Patients With HBeAg-Positive Chronic Hepatitis B. J Infect Dis. 2018,218(7):106674.

16. Wang X, Wang Z, Chi X, Wu R, Jin Q, Xu H, et al. Efficacy of a combination of HBV RNA and HBeAg in predicting HBeAg seroconversion in patients treated with entecavir for 144 weeks. Int J Infect Dis. 2020,99:171-8.

17. Giersch K, Allweiss L, Volz T, Dandri M, Lütgehetmann M. Serum HBV pgRNA as a clinical marker for cccDNA activity. J Hepatol. 2017,66(2):460-2.

18. Jansen L, Kootstra NA, van Dort KA, Takkenberg RB, Reesink HW, Zaaijer HL. Hepatitis B Virus Pregenomic RNA Is Present in Virions in Plasma and Is Associated With a Response to Pegylated Interferon Alfa-2a and Nucleos(t)ide Analogues. J Infect Dis. 2016,213(2):224-32.

19. van Bömmel F, Bartens A, Mysickova A, Hofmann J, Krüger DH, Berg T, et al.Serum hepatitis B virus RNA levels as an early predictor of hepatitis $B$ envelope antigen seroconversion during treatment with polymerase inhibitors. Hepatology. 2015,61(1):66-76.

20. Huang H, Wang J, Li W, Chen R, Chen X, Zhang F, et al. Serum HBV DNA plus RNA shows superiority in reflecting the activity of intrahepatic cccDNA in treatment-naïve HBV-infected individuals. J Clin Virol. 2018,99-100:71-8.

21. Dahari H, Shlomai A, Cotler SJ. Early HBV RNA kinetics under NA treatment may reveal new insights into HBV RNA dynamics and NA mode of action-more detailed kinetic studies are needed. J Viral Hepat. 2021,28(4):687-8.

22. Meena BL, Premkumar M, Roy A, Singh V. Is HBV RNA a valid marker for predicting sustained viral response for nucleoside analogue cessation? Gut. 2020,gutjnl-2020-323360.

23. Abraham TM, Loeb DD. The topology of hepatitis B virus pregenomic RNA promotes its replication. J Virol. 2007,81(21):11577-84.

24. Tsuge M, Murakami E, Imamura M, Abe H, Miki D, Hiraga N,et al. Serum HBV RNA and HBeAg are useful markers for the safe discontinuation of nucleotide analogue treatments in chronic hepatitis B patients. J Gastroenterol. 2013,48(10):1188-204.

Page $10 / 14$ 
25. van Bömmel F, Bartens A, Mysickova A, Hofmann J, Krüger DH, Berg T,et al. Serum hepatitis B virus RNA levels as an early predictor of hepatitis $B$ envelope antigen seroconversion during treatment with polymerase inhibitors. Hepatology. 2015 ,61(1):66-76.

26. Butler EK, Gersch J, McNamara A, Luk KC, Holzmayer V, de Medina M, et al. Hepatitis B Virus Serum DNA andRNA Levels in Nucleos(t)ide Analog-Treated or Untreated Patients During Chronic and Acute Infection. Hepatology. 2018,68(6):2106-2117.

27. Mak LY, Cloherty G, Wong DK, Gersch J, Seto WK, Fung J, Yuen MF. HBV RNA profiles in chronic hepatitis B patients under different disease phases and anti-viral therapy. Hepatology. 2020,6.

28. Jia W, Zhu MQ, Qi X, Wang T, Wen X, Chen PD, et al. Serum hepatitis B virus RNA levels as a predictor of HBeAg seroconversion during treatment with peginterferon alfa-2a. Virol J. 2019,16(1):61.

29. Luo H, Zhang XX, Cao LH, Tan N, Kang Q, Xi HL, et al. Serum hepatitis B virus RNA is a predictor of HBeAg seroconversion and virological response with entecavir treatment in chronic hepatitis B patients. World $\mathrm{J}$ Gastroenterol. 2019,25(6):719-28.

30. Liu S, Zhou B, Valdes JD, Sun J, Guo H. Serum Hepatitis B Virus RNA: A New Potential Biomarker for Chronic Hepatitis B Virus Infection. Hepatology. $2019,69(4): 1816-27$.

31. Liu S, Wu Y, Deng R, Shen S, Fan R, Peng J, et al. Methodology-dependent performance of serum HBV RNA in predicting treatment outcomes in chronic hepatitis B patients. Antiviral Res. 2021,189:105037.

\section{Figures}
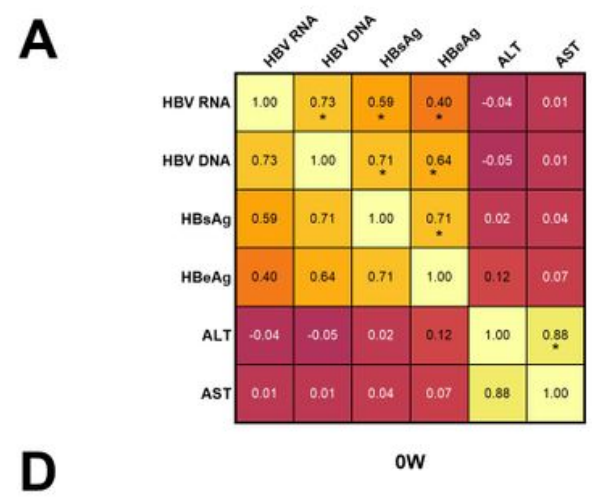

ow

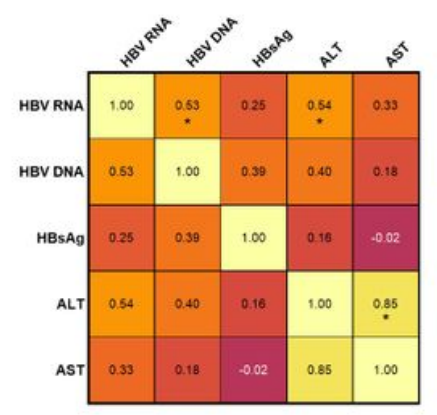

ow

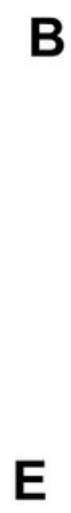

E

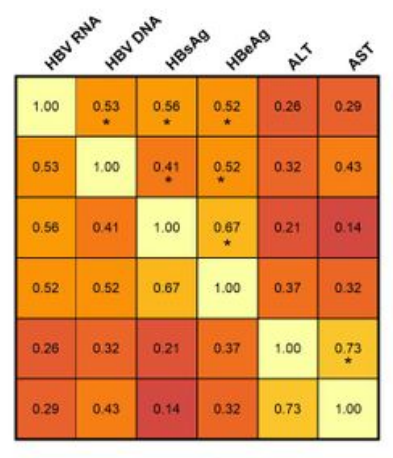

$12 \mathrm{~W}$

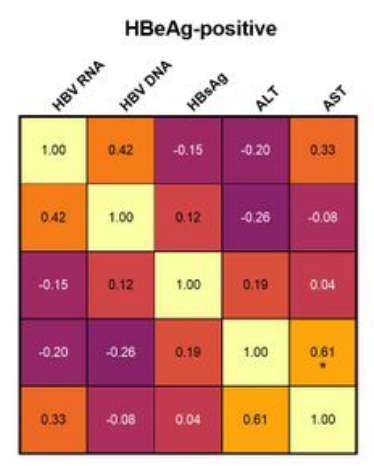

$12 \mathrm{~W}$

HBeAg-negative

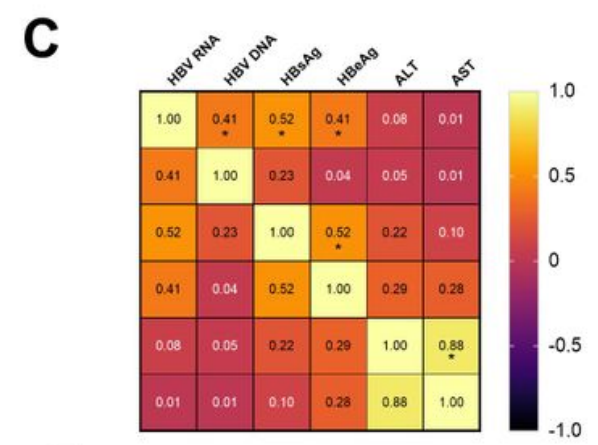

$\mathbf{F}$

$24 W$

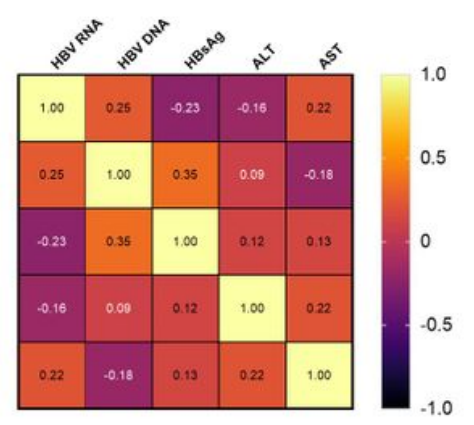

$24 \mathrm{~W}$

\section{Figure 1}

Correlation of serum HBV RNA with other HBV biomarkers in CHB patients on NAs therapy by HBeAg status. Correlation between serum HBV RNA and other HBV indicators were analyzed using Spearman analysis. Number means Spearman 

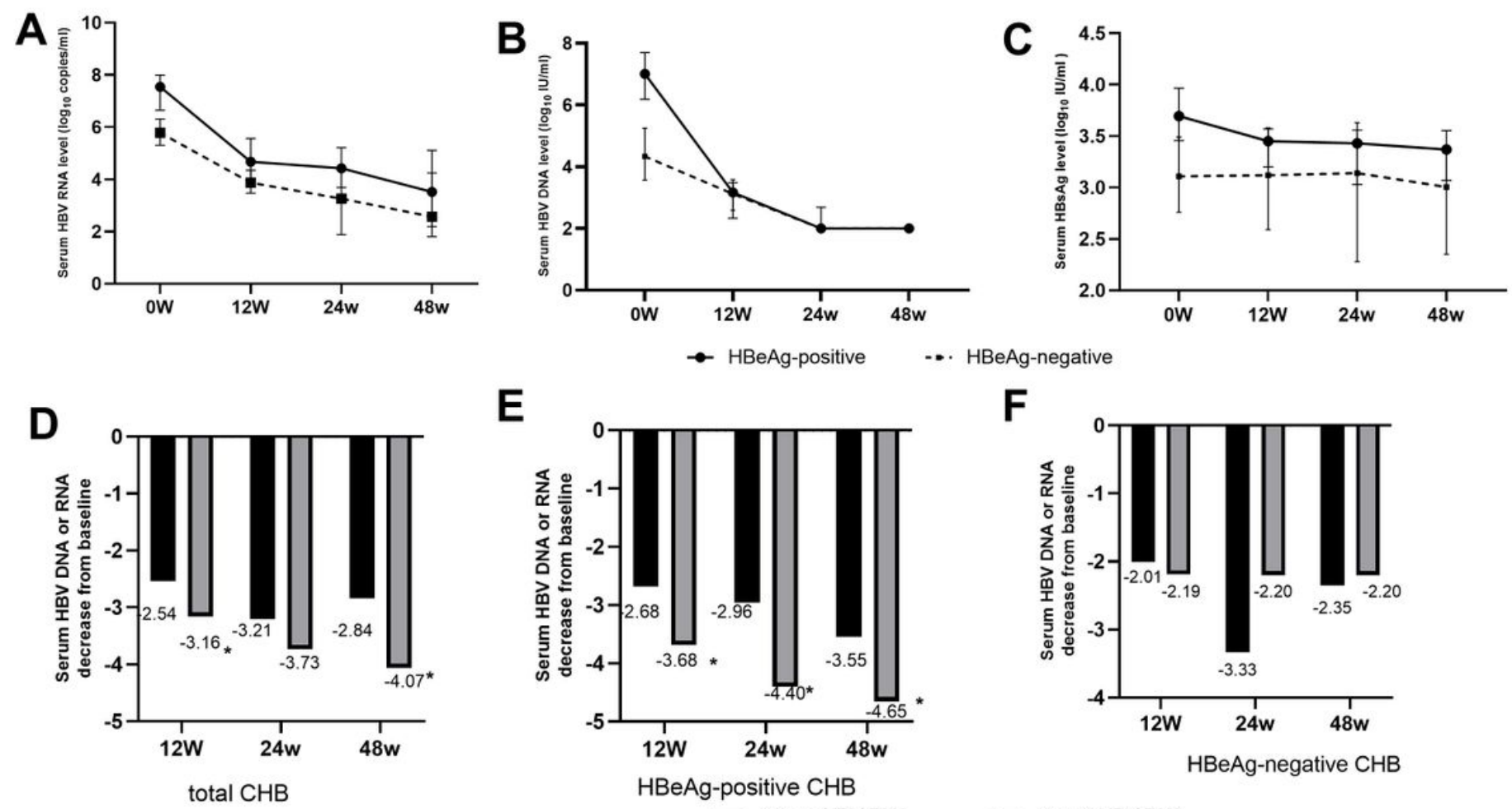

E
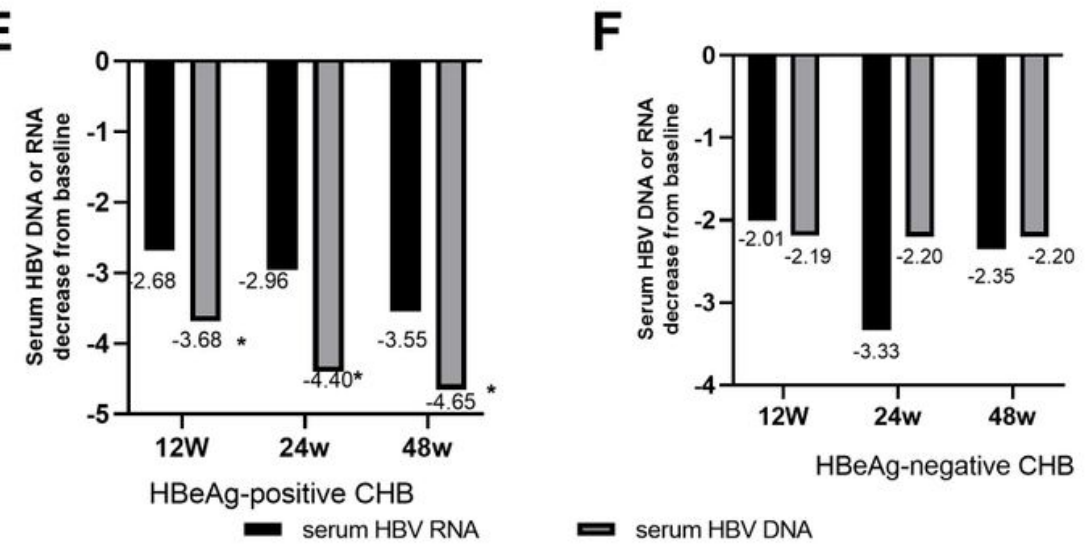

Figure 2

Kinetics and mean change from baseline of serum HBV RNA, HBV DNA level, and HBsAg titer in CHB patients on NA treatment by $\mathrm{HBeAg}$ status at baseline. Dot and error bar shows median (interquartile range, IQR). ${ }^{*}<0.05$, Mann-Whitney $U$ test indicates statistical significance between HBV RNA and DNA decrease degree from baseline at same timepoint and indicated by stars. A: serum HBV RNA; B: serum HBV DNA; C: Serum HBsAg; D: serum HBV RNA and DNA decrease degree in total CHB patients; E: serum HBV RNA and DNA decrease degree in HBeAg-positive CHB patients; D: serum HBV RNA and DNA decrease degree in $\mathrm{HBeAg}$-negative $\mathrm{CHB}$ patients. 

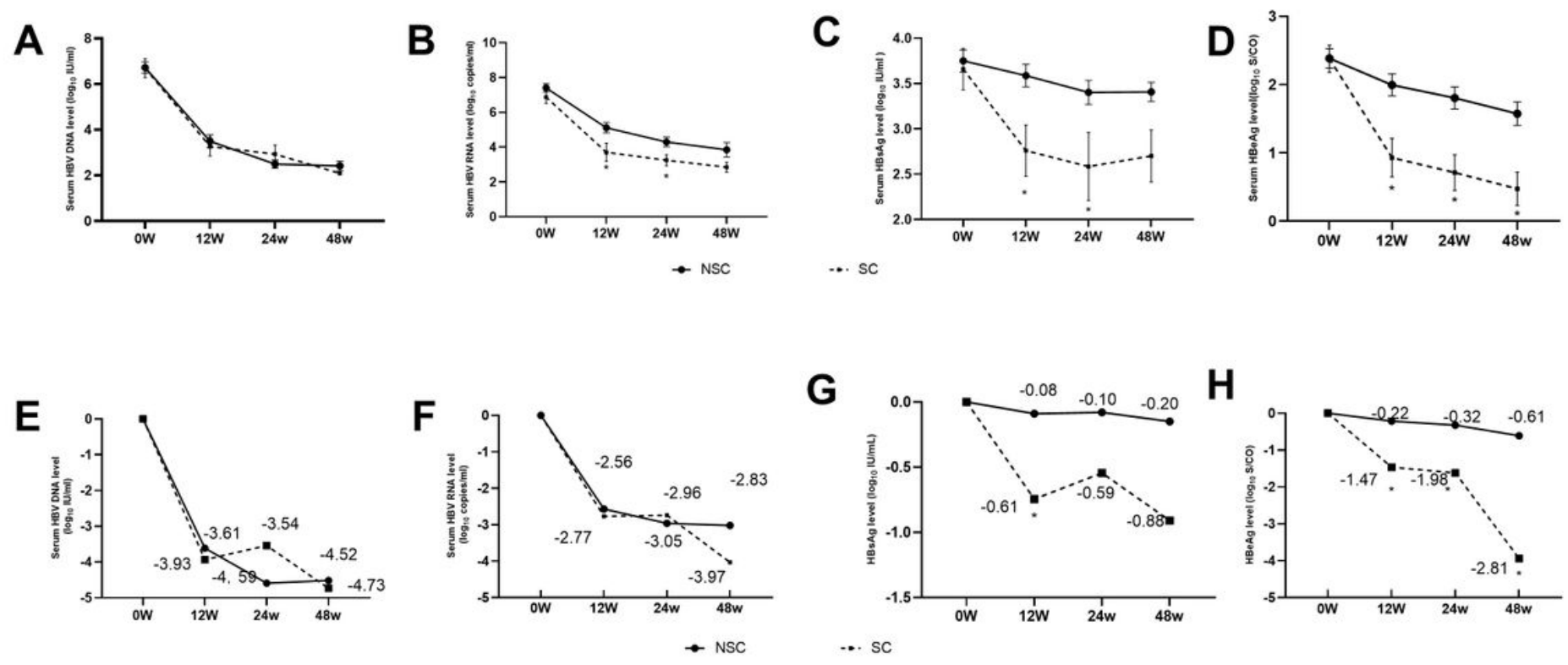

Figure 3

Kinetics and mean change from baseline level in HBeAg-positive CHB patients by serum HBeAg seroconversion response. The symbol represents mean level and median decrease from baseline level at each timepoint and with statistically significance between two groups $\varangle \mathrm{P}<0.05$, Mann-Whitney $U$ test $\$ indicated by stars. A-D shows the median indicators level at different timepoint, A: Serum HBV DNA; B: HBV RNA; C: HBsAg; D: HBeAg; E-H shows the median decrease from baseline indicators level: E: Serum HBV DNA; F: HBV RNA; G: HBsAg; H: HBeAg. Abbreviations: HBV, hepatitis B virus; HBeAg, hepatitis $B$ e antigen; HBsAg, hepatitis B surface antigen.
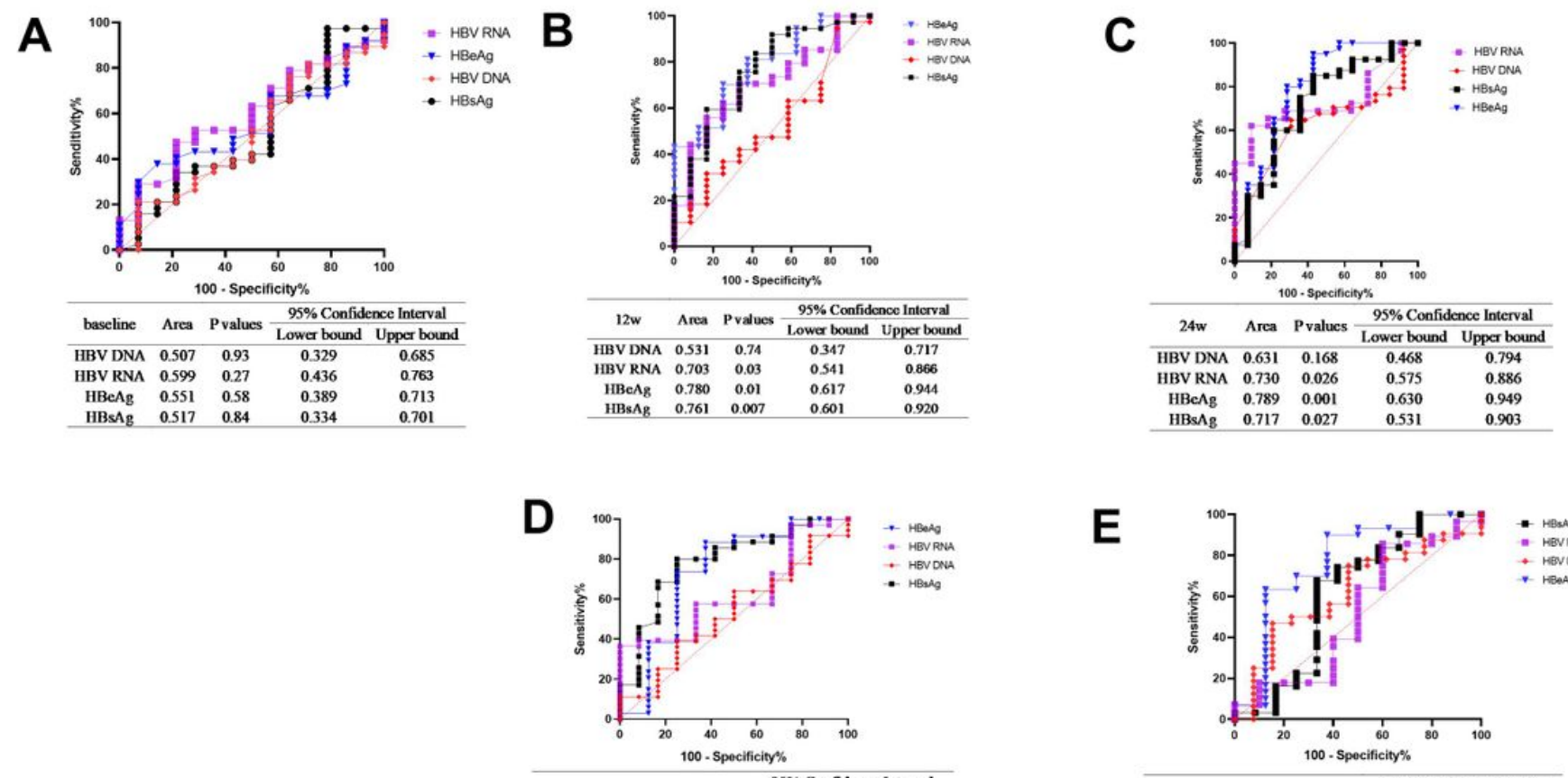

E
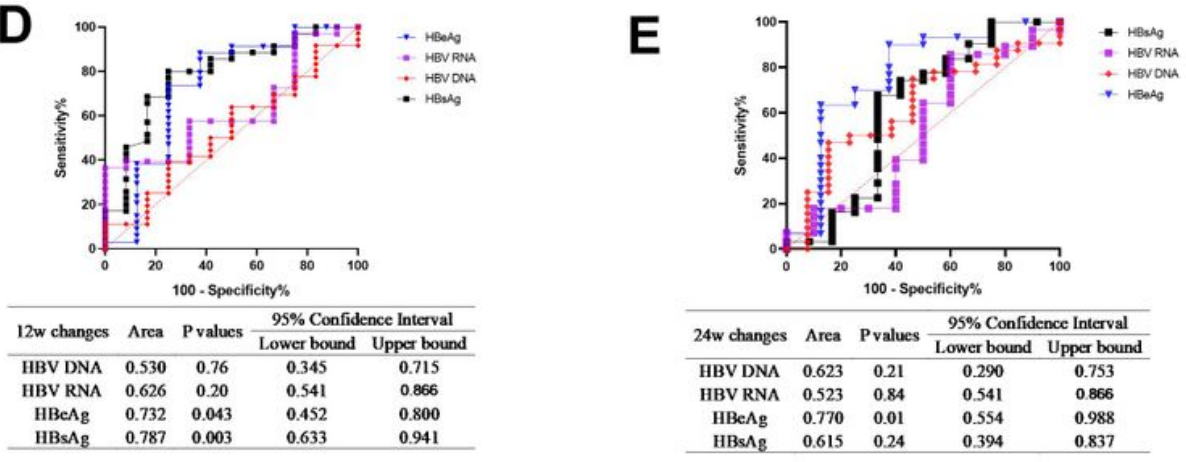

Figure 4 
Predictive value of viral indicators at different timepoint for HBeAg seroconversion in patients on NAs therapy. Receiver operating characteristic curve (ROC) is used and $p<0.05$ means statistical significance. The absolute value and change from baseline level at different timepoint were analyzed. A to $C$ : absolute value at different timepoint of treatment; $A$ : baseline; B: 12 weeks of treatment; C: 24 weeks of treatment; D: change from baseline at 12 weeks of treatment; $E$ : change from baseline at 24 weeks of treatment.

\section{Supplementary Files}

This is a list of supplementary files associated with this preprint. Click to download.

- supplementaryfile.docx 